\title{
CONTINUING PROFESSIONAL TRAINING OF PHARMACEUTICAL INDUSTRY PERSONNEL USING REMOTE TECHNOLOGIES
}

\author{
Liudmyla Klos, \\ Postgraduate student at the Department of Medical and Biological Physics and Informatics National Medical University named \\ after O.O.Bohomolets \\ https://orcid.org/0000-0002-9972-2884, e-mail: mila0712@ukr.net
}

\begin{abstract}
.
Relevance: the need for the development and experimental verification of lifelong learning, namely: microbiology, virology and immunology of future Masters of pharmacy (during studying in higher educational institution and after its graduation, their professional career in the context of society informatization).

Aim: to analyze the state of preparation of Masters of pharmacy in the study of microbiology, virology and immunology in the conditions of society informatization.

Methods: theoretical (analysis, synthesis, generalization); empirical (expert evaluation and self-assessment methods; questionnaire).

Results: the modernization update of the purpose and contents of teaching the future Masters of pharmacy in microbiology, virology and immunology is proposed. An attempt has been made to introduce such a system of training, which would be aimed at the formation of professional knowledge of future Masters of pharmacy, continuous improvement of their professional competences, meaningful practical application of the obtained theoretical knowledge and the acquisition of new knowledge (that appears in the scientific space), the formation of appropriate skills, effective communication formation in the professional pharmaceutical environment through remote technologies.

Conclusions: the author has proved that the profession of provisor is inherently a process of constant selfdevelopment and self-improvement, with the help of which pharmaceutical activity will be effective. Considering that the pharmaceutical industry has undergone significant changes in comparison with the last century, and requires continuous scientific and educational education, it is concluded that the modern provisor should be able to improve his personal professional qualification at the convenient time for him, remotely, including by online and offline.
\end{abstract}

Keywords: distance learning, educational institution, information technologies, Master's degree, training, educational process, preparation, provisor, pharmacist.

Introduction. The accession of our country to the European community, the informatization of society, the development of technologies in various fields, in particular, pharmaceutical one, give impetus to the implementation of integration processes in education (Vlasenko, 2017, pp. 12-14). An important component of Ukraine's education system is higher pharmaceutical education, the nature of which is aimed at building the competencies of health care professionals, the level of which should be equivalent to trends in society. In recent years, there has been a need to review and update the training system for these specialists. After all, maintaining public health is the key to the well-being and prosperity of both the state and society as a whole.

The good health of the nation not only increases the life expectancy and quality of life, but also improves the efficiency and working capacity of the population as a result of improving the economic and material situation of the population and the country as a whole. Health and safety issues have always been at the forefront of social and economic and cultural life in our 
country every citizen and the relevant health care system, including pharmaceutical specialists, should be concerned about the state of health.

An analytical review of the specific training of pharmaceutical industry professionals identified a number of related problems that need to be addressed:

- substantiation of theoretical and practical principles of pharmaceutical education management in the conditions of dynamic development of social and economic changes;

- providing the pharmaceutical industry specialists with qualitatively new scientific knowledge in accordance with requirements that are constantly changing and forming into a dynamic system;

- defining directions of innovative changes in the development of pharmaceutical education;

- finding and developing a model that incorporates a variety of training forms and methods.

Sources of research. Knowledge of biology, chemistry, pharmacology, manufacturing technology of medicine, epidemiology, microbiology, virology and immunology, economics and marketing, etc. is important for Masters of pharmacy in the formation of their professional competencies and usage in professional activity. Provisors should always be informed about the health of the population and the types of diseases that are circulating in their area. Because, quite often, they have to embody not only the function of selling medicine, but also the selection of their analogs, alternatives and so on. Provisors often help to determine which medicine to choose for the patient. Those needs are the most acute during the epidemiological morbidity of the population.

The professional training of future Masters of pharmacy requires appropriate compliance with the rules, regulations and standards of the European Higher Pharmaceutical Education Area. The leading goal of the possible innovation in education is the training of highly qualified specialists Masters of pharmacy, who, in addition to their professional skills, will have such qualities as mobility and competitiveness not only in the national, but also in the world labor market (Karpenko, 2014).

In 2011, The concept "Pharmatist of Seven Stars" (joint FIP / WHO guidelines on good pharmacy practice: standards for quality of pharmacy services, 2011) was developed on the joint recommendations of WHO and the International Pharmacists' Federation: Good Pharmacy Practice: Pharmacy Service Quality Standards. It says that:

- a specialist providing high quality pharmaceutical assistance;
- $\quad$ the person making the qualified decision;

- communicator a specialist who is the intermediary between the doctor and the person in need of pharmaceutical care;

- manager an employee with managerial qualities, with economic and financial knowledge;

- lifelong learner a specialist who obtains and updates his/her professional knowledge, starting from basic education and throughout his/her career;

- mentor to be a facilitator for his colleagues and mentees;

- a leader an employee who is able to make management decisions in complex situations that are aimed at the well-being of the patient and the general population.

Among the well-known scientists who have made significant contributions to the pharmaceutical field, the following researchers are worth to mention: F.I. Gize, E.S. Gordienko, Y.A. Gromov, G.G. Koritari, A.D. Chirikov, and M. O Valyashko, O.I. Cherkes and others. At the same time, the works of scientists engaged in the study of the development of pharmaceutical education and professional training of specialists in the pharmaceutical field, in particular, are the scientific developments of K. Amosova, D. Volokh, B. Gromovik, B. Zimenkovsky, I. Zupants, and Z. Mnushko., T. Kalyniuk, L. Kaydalova, A. Nemchenko, M. Syatin, V. Tolochko, Y. Tsehmister, V. Chernykh, O. Chaliy and others. Important changes in the social and economic relations in the current Ukrainian society require the training of specialists in new, not traditional forms (Provision on distance learning at National University of Pharmacy, 2016): network, mixed, distance, etc.; these forms of education are regulated by the following regulatory framework:

- Law of Ukraine "On Education” No. 1060XII of May 23, 1991, as amended (Verkhovna Rada of Ukraine. Legislation of Ukraine, 2011);

- Law of Ukraine "On Higher Education" edition of 09.08.2019 № 1556-VII (Verkhovna Rada of Ukraine. Legislation of Ukraine, 2019);

- Law of Ukraine "On Basic Principles of Development of the Information Society in Ukraine for 2007-2015" No. 537-V of 09.01.2007 (Verkhovna Rada of Ukraine. Legislation of Ukraine, 2007);

- Decree of the Ministry of Education and Science of Ukraine No. 466 of April 25, 2013 "Provision on Distance Learning” (Verkhovna Rada of Ukraine. Legislation of Ukraine, 2013a);

- Decree of the Ministry of Education and Science of Ukraine No. 1518 of 30.10.2013 "Requirements for higher educational establishments and institutions of postgraduate education, scientific 
and educational institutions providing educational services in distance learning (training and advanced training of specialists in accredited fields and specialties)" (Verkhovna Rada of Ukraine. Legislation of Ukraine, 2013b);

Decree of the Ministry of Education and Science of Ukraine No. 450 dated August 7, 2002 "On approval of the norms of time for planning and accounting of educational work and lists of the main types of methodological, scientific and organizational work of pedagogical and scientific-pedagogical employees of higher educational institutions" (Verkhovna Rada of Ukraine. Legislation of Ukraine, 2002).

The purpose of the paper is to analyze the state of preparation of Masters of pharmacy in the study of microbiology, virology and immunology in the conditions of society informatization.

Methods: theoretical (generalization, analysis and synthesis in order to find out the state and level of development of the problem under study, regarding the readiness of Masters of pharmacy to use remote technologies in the process of learning); empirical (expert evaluation and self-assessment methods; questionnaire).

Results and discussion. The growth of the role and status of Masters of pharmacy is observed in the period of high technology development in the world society. This can be explained, firstly, by certain progressive lines of development in the medical, pharmaceutical and pharmacology fields (trends in the upgrading of industry technologies, means and devices of professional use, growth of the range of medicines), and secondly, by corresponding demographic trends, such as an increase in the number of diseases that are combined with the way of life of people, life expectancy, chronic diseases, thirdly, the emergence of new strains of viruses and bacteria due to mutations, the appearance of new genetically engineered biological medicine and so on. All these factors lead to the emergence of new specialists in the field of pharmacy clinical pharmacists who will combine the analytical thinking of the doctor and pharmaceutical knowledge (Clinical Pharmacy Educational Program, 2016, pp. 2). Microbiology, virology, immunology, pharmacology, genetic engineering, and dynamically changing sciences are at the forefront of knowledge of these specialists. This, in turn, necessitates the renewal of basic knowledge gained in these disciplines through distance learning.

Higher pharmaceutical education can be obtained both on a full-time and part-time basis. Recently, there has been a tendency to increase the number of students who want to get pharmaceutical education on part-time basis. We conducted a survey of part-time students of the Faculty of Pharmacy through testing. The purpose of this study was to establish a primary level of knowledge in biology, microbiology, virology and immunology. The test form included 10 questions on the biology course that students studied in their first year of study.

The test data were evaluated on a 5-point scale using the following criteria: 5 points 10 correct answers (meets high level of knowledge). 4 points 8-9 correct answers (sufficient level of knowledge), 3 points 67 correct answers (satisfactory level of knowledge), 2 points 5 and less correct answers (low level of knowledge).

Analyzing the results of the study (shown in Fig. 1) it can be seen that over $51 \%$ of students have a low level of knowledge, $33 \%$ satisfactory and only about $16 \%$ a sufficient level. We come to the conclusion that there is a need to introduce a new method of training future employees of the pharmaceutical industry remote one, which is based on new information technologies that are combined with the principles of self-education.

Distance learning provides an opportunity for each student to choose his own convenient time to master the study material, without limiting his classroom framework. This form of study is a flexible, individualized process that allows you to study and work, optimize your free time, choose the best teachers and work on more advanced programs, both online and offline, without being within the walls of the educational institution.

We conducted an experiment to introduce distance learning of microbiology, virology and immunology to students of the Faculty of Pharmacy with the purpose of comparative analysis of competences of students of correspondence form of study.

The Table 1 shows the values of the average assessment of practical classes and final control of knowledge of students of the experimental group and the control group.

Notes: Distribution law of indicators was different from the normal one; median value and interquartile range were calculated for data presentation. The Mann-Whitney test was used in the comparison.

The comparison showed an average assessment

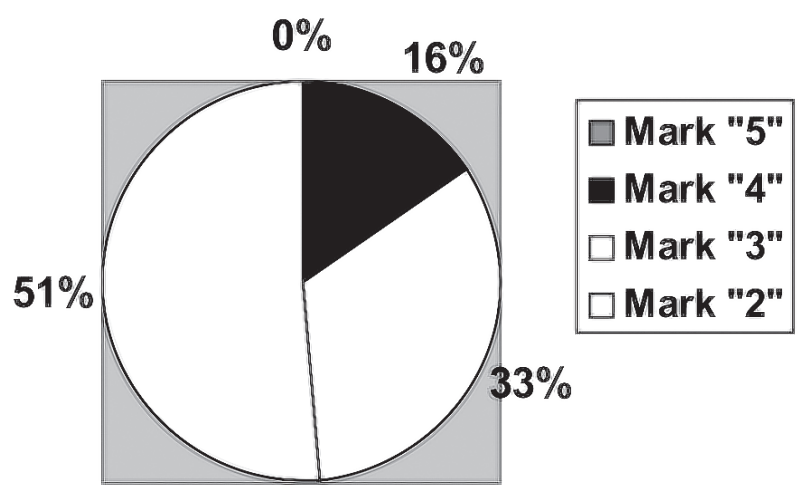

Fig. 1. Assessment of part-time students' knowledge in Biology; the Faculty of Pharmacy 
Table 1

Comparison of learning outcomes of students of control and experimental groups

\begin{tabular}{|c|c|c|c|}
\hline \multirow[t]{2}{*}{ Measure indicator } & \multicolumn{2}{|c|}{ Me (QI - QIII) } & \multirow{2}{*}{$\begin{array}{c}\text { Difference significance } \\
\text { level, } p\end{array}$} \\
\hline & Control group $(n=46)$ & Experimental group $(n=53)$ & \\
\hline $\begin{array}{l}\text { Average assessment for } \\
\text { practical lessons }\end{array}$ & $6,2(6,0-6,2)$ & $9,4(8,8-9,7)$ & $<0,001$ \\
\hline $\begin{array}{l}\text { Assessment of final } \\
\text { knowledge control }\end{array}$ & $50(20-50)$ & $50(50-60)$ & $<0,001$ \\
\hline
\end{tabular}

increase $(p<0.001)$ for practical training in the experimental group, compared with the control group by 3.1 points in average (95\% CI 2.8 points 3.2 points). There was also an assessment increase $(p<0.001)$ of the final knowledge control in the experimental group compared to the control group by 10 points in average (95\% CI 0 points -20 points).

The urgency of the problem of the study of distance learning of future Masters of Pharmacy is exacerbated by the revealed contradictions between:

- the development of the pharmaceutical industry, which is undergoing significant changes and requires continuous scientific and educational support and the lack of a flexible system of distance learning for future Masters of Pharmacy;

- $\quad$ the need to solve the problems of effective therapy, pharmaceutical care, prevention of infectious diseases and the lack of innovative adaptive methodological training systems for future Masters of Pharmacy;

- the need for changes in updating the system of education of future Masters of Pharmacy and insufficient addressing of these issues at different levels of education;

- innovative conditions and needs of the public in the conditions of globalization of society and the inability of pharmaceutical industry employees to adapt to them;

- changing requirements for the professional competencies of specialists in the pharmaceutical industry and lack of preparedness for the higher education system (Kaidalova, 2011).
Solving these problems points to the need to rethink and modernize the purpose, contents and tasks of future Masters of Pharmacy. It is believed that such a system should be aimed at the formation of professional knowledge of future Masters of Pharmacy, continuous improvement of professional competences, meaningful practical application of the obtained theoretical knowledge and the acquisition of new information that appears in the scientific space, the formation of appropriate skills.

Conclusions. Today requires careful study, understanding and improvement of methodological assistance to future Masters of Pharmacy. Currently, it points to the need to review the foreign experience of teaching future Masters of pharmacy in this direction (with the possibility of borrowing some aspects), in particular, in the field of continuity of education and integration of knowledge from different disciplines the introduction of distance learning. It is explained by the emergence of new infectious diseases, mutation of bacteria and viruses, which are one of the strongest means of natural selection; the dynamics of modern immunology; innovations in the field of viral biochemistry, biotechnology and molecular biology, genetics, ontogeny and pathogenesis. Introducing distance education in the pharmaceutical healthcare industry will help to prepare a highly intelligent, versatile educated employee in the healthcare industry who will be able to provide qualitative pharmaceutical assistance at all levels, deepen and embody his knowledge throughout his life.

\section{List of references}

DOCPLAYER, 2016. Положення про дистаниійну форму навчання в національному фармацевтичному університеті. Пол. А.2.2-15-032. [online] Доступно: <https://docplayer.net/86440617-Polozhennya-pro-distanciynu-formunavchannya-v-nacionalnomu-farmacevtichnomu-universiteti.html $>$ [Дата звернення 20 Вересень 2019].

Верховна Рада України. Законодавство України, 2002. Наказ МОН України, 2002, від 07.08.2002 p. № 450 «Про затвердження норм часу для планування і обліку навчальної роботи та переліків основних видів методичної, наукової й організаційної роботи педагогічних і науково-педагогічних працівників вищих навчальних закладів». [online] (Останнє оновлення 07 Серпень 2013) Доступно: <https://zakon.rada.gov.ua/laws/show/z0698-02> [Дата звернення 20 Вересень 2019].

Верховна Рада України. Законодавство України, 2007. Закон України «Про основні засади розвитку інформаиійного суспільства в Украӥні на 2007-2015 роки» від 09.01.2007 p. № 537-V. [online] (Останнє оновлення 06 Лютий 2007) Доступно: <https://zakon.rada.gov.ua/laws/show/537-16> [Дата звернення 20 Вересень 2019].

Верховна Рада України. Законодавство України, 2011. Закон України «Про освіту» від 05.09.2017 p. № 2145 VIII. [online] (Останнє оновлення 09 Серпень 2019) Доступно: $<$ https://zakon3.rada.gov.ua/laws/show/2145-19> [Дата звернення 20 Вересень 2019]. 
Верховна Рада України. Законодавство України, 2013а. Наказ МОН України 2013а від 25.04.2013 р. № 466 «Положення про дистаниійне навчання». [online] (Останнє оновлення 21 Серпень 2015) Доступно: <https://zakon. rada.gov.ua/laws/show/z0703-13> [Дата звернення 20 Вересень 2019].

Верховна Рада України. Законодавство України, 2013b. Наказ МОН України 2013b, від 30.10.2013 р. № 1518 «Вимоги до вищих навчальних закладів та закладів післядипломної освіти, наукових, освітньо-наукових установ, що надають освітні послуги за дистанційною формою навчання з підготовки та підвищення кваліфікації фахівичів за акредитованими напрямами і спеціальностями». [online] (Останнє оновлення 30 Жовтень 2013) Доступно: $<$ https://zakon.rada.gov.ua/laws/show/z1857-13> [Дата звернення 20 Вересень 2019].

Верховна Рада України. Законодавство України, 2019. Закон України «Про вищу освіту» редакиія від 09.08.2019 p. № 1556-VII. [online] (Останнє оновлення 09 Серпень 2019) Доступно: <https://zakon.rada.gov.ua/laws/show/155618> [Дата звернення 20 Вересень 2019].

Власенко, І. Г., 2017. Впровадження дистанційного навчання - вимога Сучасності. В: Дистанційне навчання як сучасна освітня технологія: матеріали міжвузівського вебінару. Вінниця, Україна, 31 Березень 2017. Вінниця : BTEI KHTEУ, [online], c. 12-14.

Кайдалова, Л. Г., 2011. Теоретичні та методичні засади неперервної професійної підготовки майбутніх фахівців фармацевтичного профілю: автореф. Доктор наук. Класичний приватний університет (м. Запоріжжя).

Карпенко, М. М., 2014. Розвиток дистанційного навчання як відповідь на сучасні виклики для України. Стратегічні пріоритети, [online] 4(33), с. 102-105. Доступно: <http://sp.niss.gov.ua/content/articles/fi les/18-1435918091. pdf $>$ [Дата звернення 20 Вересень 2019].

Освітня програма «Клінічна фармація», 2016. Молодість фармащиї: газета нащіонального фармацевтичного університету, 3 (142), с. 2.

Joint FIP / WHO Guidelines on Good Pharmacy Practice: standards for quality of pharmacy services, 2011. WHO Technical Report Series, 961, [online] Доступно: <http://mtd.dec.gov.ua/images/doc/GPP_2011_FIP.pdf> [Дата 3вернення 20 Вересень 2019].

\section{Translated \& Transliterated}

DOCPLAYER, 2016. Polozhennia pro dystantsiinu formu navchannia v natsionalnomu farmatsevtychnomu universyteti [Provision on distance learning at National University of Pharmacy]. Pol. A.2.2-15-032. [online] Dostupno: <https:// docplayer.net/86440617-Polozhennya-pro-distanciynu-formu-navchannya-v-nacionalnomu-farmacevtichnomu-universiteti. html>[Data zvernennia 20 Veresen 2019], [in Ukrainian].

Verkhovna Rada Ukrainy. Zakonodavstvo Ukrainy [Verkhovna Rada of Ukraine. Legislation of Ukraine], 2002. Nakaz MON Ukrainy, 2002, vid 07.08.2002 r. № 450 «Pro zatverdzhennia norm chasu dlia planuvannia i obliku navchalnoi roboty ta perelikiv osnovnykh vydiv metodychnoi, naukovoi y orhanizatsiinoi roboty pedahohichnykh i naukovo-pedahohichnykh pratsivnykiv vyshchykh navchalnykh zakladiv» [Decree of the Ministry of Education and Science of Ukraine, 2002, from 07.08.2002 № 450 "On approval of the norms of time for planning and accounting of educational work and lists of the main types of methodological, scientific and organizational work of pedagogical and scientific-pedagogical workers of higher educational institutions»]. [online] (Ostannie onovlennia 07 Serpen 2013) Dostupno: <https://zakon.rada.gov.ua/ laws/show/z0698-02> [Data zvernennia 20 Veresen 2019], [in Ukrainian].

Verkhovna Rada Ukrainy. Zakonodavstvo Ukrainy [Verkhovna Rada of Ukraine. Legislation of Ukraine], 2007. Zakon Ukrainy «Pro osnovni zasady rozvytku informatsiinoho suspilstva v Ukraini na 2007-2015 roky» vid 09.01.2007 r. № 537-V [Law of Ukraine «On the Fundamental Principles of Information Society Development in Ukraine for 2007-2015» of 09.01.2007 No. 537-V]. [online] (Ostannie onovlennia 06 Liutyi 2007) Dostupno: <https://zakon.rada.gov.ua/laws/ show/537-16> [Data zvernennia 20 Veresen 2019], [in Ukrainian].

Verkhovna Rada Ukrainy. Zakonodavstvo Ukrainy [Verkhovna Rada of Ukraine. Legislation of Ukraine], 2011. Zakon Ukrainy «Pro osvitu» vid 05.09.2017 r. № 2145-VIII [Law of Ukraine «On Education» of 05.09.2017 № 2145-VIII]. [online] (Ostannie onovlennia 09 Serpen 2019) Dostupno: $<$ https://zakon3.rada.gov.ua/laws/show/2145-19> [Data zvernennia 20 Veresen 2019], [in Ukrainian].

Verkhovna Rada Ukrainy. Zakonodavstvo Ukrainy [Verkhovna Rada of Ukraine. Legislation of Ukraine], 2013. Nakaz MON Ukrainy $2013 a$ vid 25.04.2013 r. № 466 «Polozhennia pro dystantsiine navchannia» [Decree of the Ministry of Education and Science of Ukraine 2013a dated April 25, 2013 No. 466 «Regulation on Distance Learning»]. [online] (Ostannie onovlennia 21 Serpen 2015) Dostupno: < https://zakon.rada.gov.ua/laws/show/z0703-13> [Data zvernennia 20 Veresen 2019], [in Ukrainian].

Verkhovna Rada Ukrainy. Zakonodavstvo Ukrainy [Verkhovna Rada of Ukraine. Legislation of Ukraine], 2013. Nakaz MON Ukrainy 2013b, vid 30.10.2013 r. № 1518 «Vymohy do vyshchykh navchalnykh zakladiv ta zakladiv pisliadyplomnoi osvity, naukovykh, osvitno-naukovykh ustanov, shcho nadaiut osvitni posluhy za dystantsiinoiu formoiu navchannia z pidhotovky ta pidvyshchennia kvalifikatsii fakhivtsiv za akredytovanymy napriamamy $i$ spetsialnostiamy" [Decree of the Ministry of Education and Science of Ukraine 2013b, dated 30.10.2013, № 1518 «Requirements for higher educational establishments and institutions of postgraduate education, scientific, educational and scientific institutions providing educational services in the distance form of training and advanced training of specialists in accredited fields and specialties»]. [online] (Ostannie onovlennia 30 Zhovten 2013) Dostupno: <https://zakon.rada.gov.ua/laws/show/z1857$13>$ [Data zvernennia 20 Veresen 2019], [in Ukrainian].

Verkhovna Rada Ukrainy. Zakonodavstvo Ukrainy [Verkhovna Rada of Ukraine. Legislation of Ukraine], 2019. Zakon Ukrainy «Pro vyshchu osvitu» redaktsiia vid 09.08.2019 r. № 1556-VII [Law of Ukraine «On Higher Education» edition of 09.08.2019 № 1556-VII.]. [online] (Ostannie onovlennia 09 Serpen 2019) Dostupno: <https://zakon.rada.gov.ua/laws/ show/1556-18> [Data zvernennia 20 Veresen 2019], [in Ukrainian]. 
Vlasenko, I. H., 2017. Vprovadzhennia dystantsiinoho navchannia - vymoha Suchasnosti [Introduction of distance learning is a requirement of Modernity]. V: Dystantsiine navchannia yak suchasna osvitnia tekhnolohiia: materialy mizhvuzivskoho vebinaru [In: Distance Learning as a Modern Educational Technology: Intercollegiate Webinar Materials]. Vinnytsia, Ukraina, 31 Berezen 2017. Vinnytsia: VTEI KNTEU, [online], s. 12-14, [in Ukrainian].

Kaidalova, L. H., 2011. Teoretychni ta metodychni zasady neperervnoi profesiinoi pidhotovky maibutnikh fakhivtsiv farmatsevtychnoho profiliu: avtoref. [Theoretical and methodological foundations of continuous professional training of future specialists of pharmaceutical profile: abstract]. Doktor nauk. Klasychnyi pryvatnyi universytet (m. Zaporizhzhia) [Ph.D. Classic Private University (Zaporizhzhia], [in Ukrainian].

Karpenko, M. M., 2014. Rozvytok dystantsiinoho navchannia yak vidpovid na suchasni vyklyky dlia Ukrainy [Development of distance learning in response to current challenges for Ukraine]. Stratehichni priorytety [Strategic Priorities], [online] 4(33), s. 102-105. Dostupno: <http://sp.niss.gov.ua/content/articles/fi les/18-1435918091.pdf > [Data zvernennia 20 Veresen 2019], [in Ukrainian].

Osvitnia prohrama «Klinichna farmatsiia» [Clinical Pharmacy Educational Program], 2016. Molodist farmatsii: hazeta natsionalnoho farmatsevtychnoho universytetu [Youth of Pharmacy: Newspaper of National University of Pharmacy], 3 (142), s. 2, [in Ukrainian].

Joint FIP / WHO Guidelines on Good Pharmacy Practice: standards for quality of pharmacy services, 2011. WHO Technical Report Series, 961, [online] Dostupno: <http://mtd.dec.gov.ua/images/doc/GPP_2011_FIP.pdf $>$ [Data zvernennia 20 Veresen 2019], [in English].

\section{Безперервне професійне навчання працівників фармацевтичної галузі засобами дистанційних технологій}

Людмила Клос,

аспірант кафедри медичної і біологічної фізики та інформатики Національного медичного університету ім. О.О.

Богомольця

\section{Реферат.}

Актуальність: необхідність розробки та експериментальної перевірки безперервного навчання, зокрема мікробіології, вірусології та імунології майбутніх магістрів фармації, як під час самого навчання у вищому навчальному закладі, так і після його закінчення, під час професійної кар'єри в умовах інформатизації суспільства.

Мета: аналіз стану підготовки магістрів фармації при вивченні мікробіології, вірусології та імунології в умовах інформатизації суспільства.

Методи: теоретичні (аналіз, синтез, узагальнення); емпіричні (експертного оцінювання, самооцінки, анкетування).

Результати: запропоновано модернізаційне оновлення мети і змісту навчання мікробіології, вірусології та імунології майбутніх магістрів фармації. Здійснено спробу впровадження такої системи навчання, яка була б спрямованою на формування професійних знань майбутніх магістрів фармації, неперервне вдосконалення професійних компетентностей, осмисленого практичного застосування отриманих теоретичних знань та одержання нових знань, що з'являються в науковому просторі, формування відповідних умінь і навичок, створенню ефективних комунікацій у професійному фармацевтичному середовищі за допомогою дистанційних технологій.

Висновки: автором доведено, що професія провізора за своєю сутністю є процесом постійного саморозвитку та самовдосконалення, без яких неможлива їхня ефективна фармацевтична діяльність. Враховуючи те, що фармацевтична галузь зазнала суттєвих змін, в порівнянні з минулим століттям, та потребує безперервної наукової та навчальної освіти, зроблено висновок, що сучасний провізор повинен отримати можливість підвищувати особисту професійну кваліфікацію у зручний для нього час, дистанційно, в тому числі як в режимі online, так і в режимі offline.

Ключові слова: дистаниійне навчання, заклад освіти, інформачійні технологїі, магістр, навчання, освітній процес, підготовка, провізор, фармація. 